University of Nebraska - Lincoln

DigitalCommons@University of Nebraska - Lincoln

Faculty Publications: Department of Teaching, Department of Teaching, Learning and Teacher Learning and Teacher Education

Education

2004

Perceived professional needs of Korean science teachers majoring in chemical education and their preferences for online and on-site training

Taehee Noh

Jeongho Cha

Sukjin Kang

Lawrence C. Scharmann

Follow this and additional works at: https://digitalcommons.unl.edu/teachlearnfacpub

Part of the Curriculum and Instruction Commons, and the Teacher Education and Professional

Development Commons

This Article is brought to you for free and open access by the Department of Teaching, Learning and Teacher Education at DigitalCommons@University of Nebraska - Lincoln. It has been accepted for inclusion in Faculty Publications: Department of Teaching, Learning and Teacher Education by an authorized administrator of DigitalCommons@University of Nebraska - Lincoln. 


\title{
Perceived professional needs of Korean science teachers majoring in chemical education and their preferences for online and on-site training
}

\author{
Taehee Noh, ${ }^{1}$ Jeongho Cha, ${ }^{1}$ \\ Sukjin Kang, ${ }^{2}$ \& Lawrence C. Scharmann ${ }^{3}$
}

\begin{abstract}
1 Department of Chemistry Education, Seoul National University, Seoul, 151-742, Korea 2 Department of Science Education, Jeonju National University of Education, Jeonju, Korea 3 Department of Secondary Education, Kansas State University, Manhattan, Kansas, USA

Correspondence-nohth@snu.ac.kr
\end{abstract}

\begin{abstract}
In this study, we investigated the perceived professional needs of Korean science teachers majoring in chemical education, and examined their preferences for online and on-site inservice teacher training programs. The results were also compared with those of preservice teachers. Participants were 120 secondary school teachers and 67 preservice teachers, whose majors were either chemical education or science education with emphasis in chemistry. A questionnaire consisting of a modified Science Teacher Inventory of Need and a section concerning respondents' demographic information and their use of the Internet was administered. In contrast to previous studies, the perceived needs of Korean inservice and preservice teachers were found to be very strong in all 30 needs assessment items, and their prominent needs were from all seven categories. Preservice teachers indicated significantly greater needs than inservice teachers on several items. Korean teachers generally tended to prefer online inservice to traditional on-site training programs, although they still preferred on-site types of programs in areas such as conducting
\end{abstract}

Published as International Journal of Science Education 26:10 (20 August 2004), pp 12691289. DOI: 10.1080/0950069042000205422

Copyright (C) 2004 Taylor \& Francis Ltd. Used by Permission 
laboratory sessions and demonstrating manipulative skills. Preferences for online programs tended to be stronger among preservice teachers than inservice teachers, and among non-veteran teachers than in veteran teachers. Educational implications are discussed.

\section{Introduction}

It is an implicit but widely held belief that the quality of education cannot be improved without improving the quality of teachers. Many researchers have also contended that teachers, among other factors, play a key role in effectively responding to a call for improvement in education (Fullan and Miles 1992, Walker and Cheong 1996). Thus, teachers' professional development, which involves the use of different teaching activities, the development of beliefs and conceptions underlying the activities, and the development of subject matter knowledge and skills (Bell 1998), has been one of the most important factors in efforts for educational improvement. Teachers themselves also need opportunities for their professional development in order to maintain and enhance their abilities to teach, because subject area contents as well as instructional methods are rapidly evolving and widening especially in continually changing subjects like science.

Teachers' professional development, however, has frequently been pursued without appropriate support systems. Professional development has tended to be simply equated with an on-site inservice teacher training or workshop (Loughran and Gunstone 1997). Moreover, it has not been seriously taken into account whether the teachers participating in an inservice program really acquired useful knowledge necessary for their professional development, and whether the teachers of different teaching experience and background needed particularly different knowledge. As a result, teachers are often frustrated that they still feel unable to improve the learning of their students even after taking inservice programs (Bell 1998). Teachers' complaints about inservice teacher training programs are well documented and occur in many countries. Seferoglu (1996), for example, reported that many Turkish teachers felt some inservice training workshops were conducted just for the sake of formality. Kim et al. (1991) reported that over $80 \%$ of science teachers taking an inservice teacher training program in Korea complained that it did not address the concerns

and practical problems they faced. It seems apparent that past and 
present efforts for teachers' professional development have not produced the desired results (Howe and Stubbs 1997).

One possible reason for the dissatisfactory results of inservice teacher training might be that the objectives of programs were not congruent with teachers' personal and classroom needs (Baird et al. 1993). It might be reasonable to better understand the target audience before prescribing any intervention. Thus, to simply impose a training program on teachers without considering their needs makes little sense. Needs assessment is indeed suggested to be a prerequisite for any inservice teacher training programs in order to make them feasible and relevant to teachers (Eraut 1995). Mecca and Klindienst (1987) also reported that a program planned on the basis of the expressed needs of teachers attained more positive evaluation. Several investigations regarding science teachers' needs have been made in various contexts (for example, Abu Bakar et al. 1988, Baird et al. 1994, Germann and Barrow 1995, McGinnis et al. 1996, Ramsey 1993, Zint and Peyton 2001). The results of these surveys were used either as a basis in planning inservice teacher training programs or as a prelude to setting national policy. Nonetheless, there are still few examples of inservice teacher training programs in which the providers pre-assessed teachers' needs (O'Sullivan 2000).

Recently, the development of new information and communication technology, especially the Internet, undoubtedly offers interesting and exciting possibilities in various aspects of modern society (Buchanan 1995, Halla and Lehman 1992, Robinson 1994, Sumrall and Sumrall 1995, Wood 1992). The Internet also provides an opportunity for inservice teacher training of an entirely new type - online or Web-based training. Several studies repeatedly pointed out that the problem of time and space is one of the greatest barriers for teachers to participate in traditional on-site inservice training programs, even though teachers did realize a certain deficiency in their abilities to successfully fulfil their profession (Baird et al. 1993, Barkley 2001, Germann and Barrow 1995, Levins et al. 1994). One could expect that online inservice teacher training might be an alternative to the aforementioned practical problem of on-site inservice teacher training. With online training, more teachers are probably able to find an appropriate program that fits into their schedules. They can learn at their own pace while working at their own schools. Furthermore, teachers might be able to selectively participate in some courses of an inservice teacher 
training program or choose some content to study and/or get instructional resources rather than pursue an entire program as is the case of many traditional on-site programs. Cost reduction is also a frequently cited advantage of the introduction of online inservice teacher training (Jung 2001).

Some institutes in many developed countries started to offer professional development certificates in educational media or distance education via online education several years ago (for examples from Canada, the UK, and the US, see Boone and Andersen 1995, Robinson 1991, Sherry and Morse 1995, Wiesenmayer and Koul 1998). Recently, more online inservice teacher training programs, although not yet the prevalent method of administering inservice teacher training, are provided in many developed countries as well as some developing countries (for example, Baek and Westrom 2001, Barkley and Bianco 2001, Jung 2001, Knapczyk et al. 2001). The providers of many online teacher training programs, however, seem to make the same mistake as did those of traditional training programs. That is, there is little reported research examining teachers' perceived professional needs for online inservice teacher training programs.

\section{Characteristics of educational situations in Korea}

Korea has an educational system of 6-3-3-4; six years for elementary school, three years for middle school, three years for high school, and four years for college. The colleges of education in universities are the major institutes for educating prospective secondary school teachers. For prospective teachers majoring in chemical education, there are six departments of chemical education at national universities and three at private universities (Noh et al. 1997). There are also nine departments of science education providing a curriculum in chemistry. Teacher education programs in universities and graduate schools of education are also available to prospective teachers. Teachers who possess a chemistry teaching certificate generally teach either physical science in middle schools or general science and/or chemistry in high schools. Although a new certificate program for teachers to teach physical science and/or general science courses in secondary schools has been recently established, the number of teachers with the general science teaching certificate is extremely low at present. The 
percentage of young chemistry teachers is also quite low because the Korean government has employed fewer teachers partly due to an insufficient budget for education since the early 1990 .

In terms of an infrastructure for the Internet connection, Korea is one of the best-equipped countries in the world. According to the report of the Organization for Economic Co-operation and Development (2001), Korea was reported to possess one of the highest levels of Internet subscribers per 100 inhabitants. Furthermore, in mid2000, more than one-half of the subscribers using Digital Subscriber Line connections to the Internet for high speed in the Organization for Economic Co-operation and Development reporting area were Korean. In 1997, the Korean government initiated a comprehensive sixyear project to establish an advanced educational infrastructure. As a result, every teacher possesses his/her own computer with an Internet connection using high-speed lines such as Digital Subscriber Line or Integrated Services Digital Network. Every school also possesses at least two multimedia centers with networked personal computers, and each classroom has been equipped with, at minimum, a multimedia personal computer networked by a Local Area Network system.

There exist 16 provincial offices of education in Korea, each of which provides inservice programs through teacher training centers in collaboration with nearby colleges. Since a National Curriculum for grades K-12 is implemented throughout Korea, similar inservice teacher training programs are provided to teachers regardless of province. As use of the Internet grows and expands in schools, there is an increasing need for flexible teacher training (Korea Multimedia Education Center 1998). To meet this need, the Ministry of Education and the Ministry of Information and Communication in Korea jointly funded a project to create a Cyber Teacher Training Centre within the Korea Multimedia Education Centre in 1997. The project, which was to create the Cyber Teacher Training Centre, developed a software platform for managing online teacher training and 11 general courses designed as self-directed and self-paced Web-based learning programs (Baek and Westrom 2001). In addition to the teacher training centers, several universities have offered online teacher training courses. Most courses provided by both teacher training centers and universities, however, are either too general (e.g. titles such as 'computers and the information society') or too technologically-oriented (e.g. titles such as 'instructional use of multimedia'), although some subject-specific 
online courses such as training programs for the experts in child education and general English have been recently prepared.

\section{Purposes}

Few investigations regarding science teachers' perceived needs for online inservice teacher training have been reported in the literature. Furthermore, there has never been an attempt to examine science teachers' needs for online inservice programs as well as traditional on-site ones in Korea. In a grant project to provide a 'Chemical Education Homepage' for Korean secondary teachers and college students possessing a chemistry background, we conducted assessments of perceived professional needs. The purposes of this study were to: (a) investigate Korean teachers' needs for on-site and online inservice teacher training, (b) examine their preferences for the two types of training, and (c) compare the self-reported needs according to the two teacher variables of teaching experience and school level. We also examined the perceived needs of prospective secondary teachers majoring in chemical education and their preferences for the type of training, and then compared the results with those of the inservice teachers in order to gain some implications for the direction of future inservice training as well as preservice teacher preparation programs.

\section{Methods}

\section{Instrument}

'Need' has an ambiguous, relative, and dynamic nature, so that diverse interpretations such as discrepancy, recognized problem, requirement for more services, and the wants of people (O'Sullivan 2000, Packwood and Whitaker 1988) are possible definitions. Among these various definitions of need, we adopted, in this study, Witkin's (1984) discrepancy definition, which is a measurable discrepancy between the present state of affairs and a desired state of affairs. Thus, teachers' professional need was defined as the perceived discrepancy between what teachers have and what they want to fulfil their profession well (Abu Bakar and Tarmizi 1995). It may not be suitable to 
use this definition for prospective teachers, because most may have only limited teaching experience. However, it may be more meaningful to compare the needs of inservice and preservice teachers with a common definition for the sake of this study.

There are a number of survey instruments for use in determining science teachers' needs and concerns. On choosing a needs assessment instrument, several criteria such as proven validity and reliability, encompassing a wide range of teachers' professional needs, and brevity to ensure higher return rate were considered. Zurub and Rubba (1983) developed the Science Teacher Inventory of Need (STIN). The STIN consists of 76 items organized into seven categories; (a) specifying objectives for instruction, (b) diagnosing and evaluating learners, (c) planning instruction, (d) delivering instruction, (e) managing instruction, (f) administering instructional facilities and equipment, and (g) improving personal competence as a teacher. Each of the STIN items describes tasks or activities that are needed for science teachers to carry out their instructional duties, followed by a four-point scale $(\mathrm{NF}=$ not familiar with the task, $1=$ no need, $2=$ little need, $3=$ moderate need, and $4=$ great need). The content validity of the STIN was verified by a panel of seven experts (Zurub 1982), and the Cronbach's internal consistency reliability coefficient was estimated to be 0.95 (Zurub and Rubba 1983). Baird and Rowsey (1989) modified the STIN, shortening the original instrument into 54 items by deleting, editing, and adding some items. The Cronbach's internal consistency reliability coefficient for the modified STIN was reported to be 0.96 .

In this study, we further modified the Baird and Rowsey version of the STIN. First, 24 items that were not directly relevant to educational situations in Korea were removed. The removed items included 'select and use standardized tests', 'select commercial materials for teaching', 'direct a science field trip', and 'construct science laboratory equipment', and so forth. Second, a supplemental question for respondents to indicate their preferences for the type of training such as on-site and online training was added to each item. Finally, the 'Not Familiar' option embodied in the previous versions of the STIN was also removed, because previous research documented that only few respondents had chosen this option (Baird and Rowsey 1989, Baird et al. 1993). As a result, 30 needs assessment items from the STIN were used in this study. At the end of question set, there is an open-ended item in which respondents could express any needs not addressed in 
the existing 30 items. We also added another section to the questionnaire, which consists of 12 items concerning the demographic information of respondents (e.g. principal teaching assignment and years of teaching experience) and their use of the Internet (e.g. availability of the Internet connection and experience in using the Internet). The translation of 30 items was checked by two independent experts fluent in English. The face validity of the questionnaire was established by a panel that consisted of three science educators. The initial version was then checked by 15 science teachers possessing a strong chemistry content background. The response of the teachers to the questionnaire, followed by a discussion, provided an opportunity to check whether the format and the selection of items were proper and to edit some items while preserving the original meaning. The Cronbach's internal consistency reliability coefficient for the questionnaire used in this study was determined to be 0.92 .

The needs assessment items for prospective teachers were almost identical to those used for inservice teachers, except that the phrasing 'inservice teacher training' in each item was substituted with 'course at the department of chemical (or science) education'. The section consisting of demographic information and use of the Internet consisted of eight items. The Cronbach's internal consistency reliability coefficient was determined to be 0.82 . The coefficients of 0.92 and $0.82 \mathrm{ob}-$ tained in this study were considered acceptable, especially given that the number of items used was reduced by about one-half.

\section{Procedure}

Because a complete list of science teachers' names possessing a chemistry background was not available, we used the Korean Directory of Education (Korean Federation of Teachers' Associations 1999) to sample secondary schools for this study. Based on a school distribution in metropolitan cities, small cities, and rural areas, we proportionally selected 205 schools (101 middle schools and 104 high schools) from a pool of 3988 secondary schools on the list. Packets were sent to the selected schools in November 2000, addressed to the science division heads, who were asked to deliver packets to science teachers with a chemistry background. Each packet contained a letter of transmittal explaining the survey, an anonymous questionnaire, and a self-addressed stamped envelope. We followed Borg and 
Gall's (1989) recommendations in preparing the letter of transmittal to increase response rates that included the importance of the study, assurance of confidentiality, and so forth. Four weeks later, another packet containing an additional follow-up letter was mailed to the schools that had not responded. In order to encourage mail-backs, we then telephoned most science division heads and/or teachers in the schools that had not responded to the survey. This also provided an opportunity, although not systematic, to check non-respondent bias, which indicated no differences by teaching experience and school level. Three weeks after the first follow-up letters, the second followup letters were sent to all non-respondents. As a final result, a total of 120 questionnaires (59\%) returned. Forty-four of them were from middle school science teachers having a chemistry background, and 65 were from high school chemistry teachers. The response rate of this study is comparable with those of previous studies; $43 \%$ for Baird and Rowsey (1989), 36\% for Baird et al. (1994), and 63.3\% for Germann and Barrow (1995). Among the 18 institutes in which colleges of education have chemical education divisions in Korea, three were chosen on the basis of their locations. Sixty-seven juniors and seniors who took at least two courses related to chemical education as well as several education courses participated in this survey.

The data collected through the questionnaire were analyzed using descriptive and inferential statistics with SPSS programs. The response rate on the four-point scale of each item was over $98 \%$. The response rate on the type of inservice teacher training by teachers was over $88 \%$, while that of courses by preservice teachers over $94 \%$. Indeed, four teachers designated both traditional and online training as their preferences in all items despite the direction to choose only one, which indicated that some teachers strongly preferred to have both types of training programs. The available-case procedure that excludes cases test by test was used for analyses (Little and Rubin 1987).

\section{Demographics of subjects}

Demographic information for teachers who participated in this study is summarized in Table 1. According to Burden (1979), there are three stages in teacher development; a survival stage (first year), an adjustment stage (second year to fourth year), and a mature stage (fifth year and above). In this study, we classified the teachers who 
Table 1. Demographic information for teachers.

\begin{tabular}{|c|c|}
\hline & Frequency (\%) \\
\hline \multicolumn{2}{|l|}{ Gender $(n=120)$} \\
\hline Male 77 & $(64.2)$ \\
\hline Female 43 & $(35.8)$ \\
\hline \multicolumn{2}{|l|}{ Age $(n=118)$} \\
\hline Less than 25 years & $4(3.4)$ \\
\hline $25-30$ years & $17(14.4)$ \\
\hline $31-40$ years & $52(44.1)$ \\
\hline $41-50$ years & $42(35.6)$ \\
\hline \multicolumn{2}{|l|}{ More than 50 years $3(2.5)$} \\
\hline \multicolumn{2}{|l|}{ Teaching experience $(n=118)$} \\
\hline Less than 5 years & $20(16.9)$ \\
\hline $5-10$ years & $16(13.6)$ \\
\hline $11-20$ years & $51(43.2)$ \\
\hline More than 20 years & $31(26.3)$ \\
\hline \multicolumn{2}{|l|}{ Highest academic degree $(n=120)$} \\
\hline Bachelor's degree & $77(64.2)$ \\
\hline Master's degree & $41(34.2)$ \\
\hline Doctoral degree & $2(1.7)$ \\
\hline \multicolumn{2}{|l|}{ School $(n=120)$} \\
\hline Middle school & $46(38.3)$ \\
\hline High school & $74(61.7)$ \\
\hline \multicolumn{2}{|l|}{ Teaching assignment $(n=120)$} \\
\hline Physical science & $26(21.7)$ \\
\hline Physical science and life science & $19(15.8)$ \\
\hline General science & $6(5.0)$ \\
\hline Chemistry & $46(38.3)$ \\
\hline General science and chemistry & $23(19.2)$ \\
\hline
\end{tabular}

had less than five years of teaching experience as non-veteran teachers and the others as veteran teachers, which was also used in Germann and Barrow's (1995) study. Twenty teachers (16.9\%) were classified as non-veteran teachers. Among veteran teachers, 16 (13.6\%) had 5-10 years of experience, 51 (43.2\%) had 11-20 years of experience, and $31(26.3 \%)$ had more than 20 years of experience. All middle school teachers taught physical science, and 19 of them (41.3\%) taught life science as well. Six high school teachers (5.0\%) taught only general science courses, 46 (38.3\%) taught chemistry courses, and 23 (19.2\%) taught both courses.

Most preservice teachers were female $(n=62,92.5 \%)$. Although one of three universities participating in this study was a woman's university, the percentage of females among preservice teachers was 
Table 2. Comparison of respondents' uses of the Internet.

\begin{tabular}{|c|c|c|c|c|}
\hline & $\begin{array}{l}\text { Veteran } \\
\text { teachers } \\
(n=98)\end{array}$ & $\begin{array}{r}\text { Non-veteran } \\
\text { teachers } \\
(n=20)\end{array}$ & $\begin{array}{r}\text { Inservice } \\
\text { teachers (\%) } \\
(n=120)\end{array}$ & $\begin{array}{r}\text { Preservice } \\
\text { teachers (\%) } \\
(n=67)\end{array}$ \\
\hline \multicolumn{5}{|l|}{ Experience of using the Internet } \\
\hline None & 1 & 0 & $1(0.8)$ & $0(0.0)$ \\
\hline Be able to browse websites & 22 & 3 & $25(20.8)$ & $6(9.5)$ \\
\hline Be able to use search engines & 66 & 14 & $81(67.5)$ & $51(81.0)$ \\
\hline Have their own websites & 8 & 3 & $12(10.0)$ & $6(9.5)$ \\
\hline Manage web server & 1 & 0 & $1(0.8)$ & $0(0.0)$ \\
\hline \multicolumn{5}{|l|}{ Major means to get instructional resources ${ }^{a}$} \\
\hline $\begin{array}{l}\text { Materials distributed from } \\
\text { educational institutes }\end{array}$ & 46 & 5 & $51(33.3)$ & $0(0.0)$ \\
\hline Resources on the Internet & 40 & 16 & $58(37.9)$ & $39(79.6)$ \\
\hline Textbooks and/or science magazines & 33 & 6 & $39(25.5)$ & $10(20.4)$ \\
\hline Others & 4 & 1 & $5(3.3)$ & $0(0.0)$ \\
\hline \multicolumn{5}{|c|}{ Degree of using the Internet in searching for instructional resources } \\
\hline Not at all & 1 & 0 & $1(0.9)$ & $0(0.0)$ \\
\hline Sometimes & 26 & 6 & $32(27.8)$ & $6(9.0)$ \\
\hline Jointly use the Internet and other sources & 57 & 10 & $68(59.1)$ & $42(62.7)$ \\
\hline Almost every time & 10 & 3 & $14(12.2)$ & $19(28.4)$ \\
\hline \multicolumn{5}{|c|}{ Usefulness of instructional resources on the Internet in teaching/studying } \\
\hline Not at all & 0 & 0 & $0(0.0)$ & $0(0.0)$ \\
\hline Little & 17 & 5 & $22(19.3)$ & $3(4.5)$ \\
\hline Moderately & 57 & 9 & $66(57.9)$ & $32(47.8)$ \\
\hline Greatly & 19 & 5 & $26(22.8)$ & $32(47.8)$ \\
\hline
\end{tabular}

a. Total frequency for teachers at this item was over the number of respondents because some had chosen more than one option.

high. However, this was expected because most college students in education and new science teachers in Korea are female. Their ages ranged from 21 to 24 years.

Both inservice and preservice teachers were also asked to respond to a series of questions concerning the use of the Internet. These data are presented in Table 2. Almost all inservice teachers (96.6\%) and all preservice teachers indicated that the Internet was available in their schools and universities. Furthermore, a number of inservice $(80.7 \%)$ and preservice $(71.6 \%)$ teachers were also able to access to the Internet at home. As a result, most inservice and preservice teachers had at least some experience in using the Internet. Teachers procured teaching and learning resources by various means such as obtaining the 
materials distributed from local educational institutes, exploring the Internet, and subscribing to science magazines. Although some preservice teachers did not use any instructional resource for their classes at all, their main instructional resource was found to be the Internet. Nonetheless, over 70\% of these inservice and preservice teachers frequently used the Internet in searching for instructional resources. Many inservice and preservice teachers also recognized the benefit of the Internet in searching for instructional resources. Eighty-one percent of teachers and $96 \%$ of preservice teachers were satisfied with the information found on the Internet.

\section{Results}

\section{Needs for professional development}

The means and standard deviations of needs designated by the respondents are summarized in Table 3. The perceived needs of Korean inservice and preservice teachers possessing a chemistry background were fairly strong in all 30 needs items. Item means ranged from 3.21 to 3.75 on a four-point Likert scale for inservice teachers, and from 3.29 to 3.81 for preservice teachers. Both inservice and preservice teachers were most interested in ways to motivate students to learn science (item D1). Their prominent needs also included defending the reasons for teaching science (item A1), preparing instructional materials (item C2), conducting a laboratory session (item D3), and updating their personal knowledge in chemistry (item G1), other science content areas (item G2), and science-societal issues (item G4). Constructing and using a test item bank (item B3) and identifying sources of free instructional materials (item F2) were other prominent needs for inservice teachers, whereas demonstrating concepts (item D4) and evaluating personal effectiveness as a teacher (item E1) were more pronounced for preservice teachers.

Means of inservice teachers' needs were higher than those of preservice teachers' needs on six items; B3, C3, D7, F2, F3, and G1. However, only the difference in item F2 (identifying sources of free instructional materials) was statistically significant $(p<0.05)$ using the Mann-Whitney U-test. For the rest of the items, means of preservice 
Table 3. Comparison of the needs perceived by inservice and preservice teachers.

\begin{tabular}{|c|c|c|c|}
\hline & Inservice & Preservice & \\
\hline Item & teachers & teachers & $u$ \\
\hline A1. Defend the reasons for teaching science in school & $3.62(0.61)$ & $3.70(0.46)$ & 3826.0 \\
\hline A2. Write knowledge, attitude, and skills objectives & $3.23(0.74)$ & $3.61(0.60)$ & $2870.0^{* *}$ \\
\hline B1. Design measurement items & $3.52(0.58)$ & $3.65(0.48)$ & 3466.0 \\
\hline B2. Use test items to diagnose learning difficulties & $3.39(0.57)$ & $3.55(0.53)$ & 3417.5 \\
\hline B3. Construct and use a test item bank & $3.59(0.59)$ & $3.46(0.66)$ & 3604.5 \\
\hline C1. Develop a lesson or unit plan for instruction & $3.30(0.72)$ & $3.50(0.64)$ & 3353.5 \\
\hline C2. Prepare instructional materials & $3.71(0.47)$ & $3.79(0.41)$ & 3624.0 \\
\hline C3. Arrange classroom environment & $3.53(0.59)$ & $3.43(0.53)$ & 3546.0 \\
\hline D1. Motivate students to learn & $3.75(0.44)$ & $3.81(0.47)$ & 3666.0 \\
\hline D2. Use an inquiry teaching strategy in teaching & $3.49(0.64)$ & $3.61(0.55)$ & 3607.0 \\
\hline D3. Conduct a laboratory session & $3.59(0.56)$ & $3.69(0.47)$ & 3674.0 \\
\hline D4. Demonstrate a concept & $3.53(0.59)$ & $3.69(0.47)$ & 3498.0 \\
\hline D5. Demonstrate a science process skill & $3.52(0.61)$ & $3.67(0.53)$ & 3481.5 \\
\hline D6. Demonstrate a manipulative skill & $3.42(0.62)$ & $3.49(0.59)$ & 3755.0 \\
\hline D7. Employ simulation techniques in teaching & $3.42(0.64)$ & $3.41(0.53)$ & 3773.5 \\
\hline D8. Employ individualized instruction & $3.38(0.61)$ & $3.39(0.65)$ & 3909.5 \\
\hline D9. Employ peer tutoring & $3.21(0.64)$ & $3.29(0.58)$ & 3704.5 \\
\hline D10. Use audio-visual equipment in instruction & $3.46(0.65)$ & $3.51(0.53)$ & 3947.0 \\
\hline D11. Use computers for teaching science & $3.48(0.57)$ & $3.65(0.51)$ & $3295.5^{*}$ \\
\hline E1. Evaluate personal effectiveness as a teacher & $3.42(0.62)$ & $3.70(0.53)$ & $2964.0^{* *}$ \\
\hline E2. Use a computer to help manage instruction & $3.30(0.65)$ & $3.57(0.56)$ & $3123.5^{* *}$ \\
\hline F1. Maintain a laboratory and equipment's & $3.36(0.63)$ & $3.46(0.53)$ & 3716.0 \\
\hline F2. Identify sources of free instructional materials & $3.67(0.52)$ & $3.49(0.61)$ & $3380.5^{*}$ \\
\hline $\begin{array}{l}\text { F3. Select supportive materials (books, films, } \\
\text { and software, etc.) for instruction }\end{array}$ & $3.43(0.63)$ & $3.36(0.64)$ & 3751.0 \\
\hline G1. Update knowledge in chemistry & $3.75(0.44)$ & $3.70(0.49)$ & 3846.0 \\
\hline G2. Update knowledge in other science content & $3.58(0.53)$ & $3.69(0.53)$ & 3538.0 \\
\hline G3. Update knowledge of science-related career opportunities & $3.44(0.56)$ & $3.48(0.56)$ & 3783.0 \\
\hline G4. Learn more about science-societal issues & $3.59(0.57)$ & $3.76(0.50)$ & $3354.5^{*}$ \\
\hline G5. Update knowledge of cognitive learning theories & $3.27(0.64)$ & $3.62(0.49)$ & $2789.5^{* *}$ \\
\hline G6. Learn more about history and philosophy of science & $3.31(0.64)$ & $3.49(0.59)$ & 3371.5 \\
\hline
\end{tabular}

Data presented as mean (standard deviation).

${ }^{*} p<0.05,{ }^{* *} p<0.01$. 
teachers' needs were higher than those of inservice teachers' needs. Statistically significant differences were found in six of the items; writing knowledge, attitude, and skills objectives (item A2), using computers for teaching science (item D11), evaluating personal effectiveness as a teacher (item E1), using a computer to help manage instruction (item E2), learning more about science-societal issues (item G4), and updating knowledge of cognitive learning theories (item $\mathrm{G}_{5}$ ).

Six inservice teachers and 13 preservice teachers responded to the open-ended item. Many of their responses were concerning specific contents/activities already covered in the existing 30 items. Among examples were misconceptions and conceptual change approaches, techniques in developing instructional materials, and performance assessment. The other needs perceived by inservice teachers were instructional materials for science club activities and summary reports on instructional method seminars. Preservice teachers mentioned instructional methods for using games in science classes, knowledge about integrated science, and knowledge about teaching practices.

Teachers' needs were compared by their background variables. The teacher independent variables selected in this study were teaching experience and school level. The results indicated that there were no statistically significant differences between veteran and non-veteran teachers. Upon comparing the needs of middle school teachers with those of high school teachers, however, statistically significant differences were found in some items $(p<0.05)$. Middle school teachers designated significantly stronger needs than high school teachers in the areas of items B2, D2, D5, and D8.

\section{Preferences for on-site and online training}

The preferences of inservice and preservice teachers for the type of training and courses are presented and compared in Table 4. Teachers preferred online training programs to traditional on-site ones in 25 needs assessment items, of which 18 were significantly $(p<0.05)$ above expected frequencies of equal preference in terms of chi-square analyses. Among the five items that teachers designated as suitable for on-site training, three were statistically significant. Preservice teachers preferred online courses for teacher preparation programs in 18 areas, of which 11 were statistically significant $(p<0.05)$. There 
Table 4. Comparison of the preferences of inservice and preservice teachers for the type of training and courses.

\begin{tabular}{|c|c|c|c|c|c|c|c|}
\hline \multirow[b]{3}{*}{ Item } & \multicolumn{3}{|c|}{ Inservice teachers } & \multicolumn{3}{|c|}{ Preservice teachers } & \multirow{3}{*}{$\begin{array}{c}\mathrm{X}^{2} \\
\text { (inservice versus } \\
\text { preservice teachers) }\end{array}$} \\
\hline & \multicolumn{2}{|c|}{ Frequency } & \multirow[b]{2}{*}{$x^{2}$} & \multicolumn{2}{|c|}{ Frequency } & \multirow[b]{2}{*}{$x^{2}$} & \\
\hline & On-site & Online & & On-site & Online & & \\
\hline $\mathrm{A} 1$ & 66 & 45 & $3.973^{*}$ & 57 & 10 & $32.970^{* *}$ & $12.839^{* *}$ \\
\hline $\mathrm{A} 2$ & 52 & 57 & 0.229 & 57 & 8 & $36.938^{* *}$ & $27.820^{* *}$ \\
\hline B1 & 31 & 76 & $18.925^{* *}$ & 51 & 15 & $19.636^{* *}$ & $38.197^{* *}$ \\
\hline B2 & 32 & 77 & $18.578^{* *}$ & 28 & 39 & 1.806 & 2.855 \\
\hline B3 & 24 & 86 & $34.945^{* *}$ & 13 & 53 & $24.242^{* *}$ & 0.112 \\
\hline $\mathrm{C} 1$ & 38 & 68 & $8.491^{* *}$ & 37 & 27 & 1.563 & $7.808^{* *}$ \\
\hline $\mathrm{C} 2$ & 38 & 72 & $10.509^{* *}$ & 28 & 35 & 0.778 & 1.664 \\
\hline $\mathrm{C} 3$ & 50 & 59 & 0.743 & 25 & 39 & 3.063 & 0.761 \\
\hline D1 & 46 & 62 & 2.370 & 30 & 35 & 0.385 & 0.209 \\
\hline D2 & 48 & 61 & 1.550 & 36 & 31 & 0.373 & 1.563 \\
\hline D3 & 65 & 44 & $4.046^{*}$ & 47 & 19 & $11.879^{* *}$ & 2.392 \\
\hline D4 & 49 & 61 & 1.309 & 52 & 15 & $20.433^{* *}$ & $18.582^{* *}$ \\
\hline D5 & 61 & 46 & 2.103 & 51 & 13 & $22.563^{* *}$ & $9.114^{* *}$ \\
\hline D6 & 81 & 26 & $28.271^{* *}$ & 51 & 16 & $18.284^{* *}$ & 0.004 \\
\hline D7 & 31 & 78 & $20.266^{* *}$ & 13 & 54 & $25.090^{* *}$ & 1.807 \\
\hline D8 & 41 & 65 & $5.434^{*}$ & 27 & 37 & 1.563 & 0.205 \\
\hline D9 & 56 & 51 & 0.234 & 30 & 36 & 0.545 & 0.773 \\
\hline D10 & 44 & 65 & $4.046^{*}$ & 17 & 48 & $14.785^{* *}$ & 3.613 \\
\hline D11 & 27 & 81 & $27.000^{* *}$ & 19 & 47 & $11.879^{* *}$ & 0.302 \\
\hline E1 & 49 & 58 & 0.757 & 40 & 26 & 2.970 & 3.585 \\
\hline E2 & 29 & 79 & $23.148^{* *}$ & 12 & 54 & $26.727^{* *}$ & 1.710 \\
\hline F1 & 45 & 62 & 2.701 & 32 & 34 & 0.061 & 0.683 \\
\hline F2 & 14 & 95 & $60.193^{* *}$ & 2 & 64 & $58.242^{* *}$ & $4.766^{*}$ \\
\hline F3 & 18 & 91 & $48.890^{* *}$ & 8 & 58 & $37.879 * *$ & 0.627 \\
\hline G1 & 21 & 89 & $42.036^{* *}$ & 17 & 49 & $15.515^{* *}$ & 1.083 \\
\hline G2 & 20 & 89 & $43.679^{* *}$ & 10 & 57 & $32.970^{* *}$ & 0.344 \\
\hline G3 & 21 & 87 & $45.370^{* *}$ & 14 & 53 & $22.701^{* *}$ & 0.054 \\
\hline G4 & 19 & 89 & $118.972^{* *}$ & 25 & 41 & $3.879^{*}$ & $8.923^{* *}$ \\
\hline G5 & 36 & 72 & $12.000^{* *}$ & 55 & 11 & $29.333^{* *}$ & $41.052^{* *}$ \\
\hline G6 & 25 & 82 & $30.364^{* *}$ & 46 & 21 & $9.328^{* *}$ & $34.911^{* *}$ \\
\hline
\end{tabular}

${ }^{*} p<0.05,{ }^{* *} p<0.01$. 
existed significant differences in nine of 12 items in which preservice teachers responded to favor traditional face-to-face courses $(p<0.01)$. The items that both inservice and preservice teachers significantly favored on-site training were items A1, D3, and D6. The tasks/activities for which both inservice and preservice teachers strongly favored online teaching were found for 11 items.

In order to examine the differences in teachers' favored training types by teaching experience, the preferences of veteran and nonveteran teachers for online and on-site inservice training were compared (Table 5). Both veteran and non-veteran teachers, on the whole, tended to favor online training. Non-veteran teachers preferred online training in 26 items, of which 14 were statistically meaningful. Veteran teachers also preferred online programs in 23 items, of which 15 were meaningful. Higher percentages of non-veteran teachers than veteran teachers favored online training in 21 items, of which three were statistically significant using chi-square analyses: defending the reasons for teaching science in school (item A1), developing a lesson or unit plan for instruction (item $\mathrm{C} 1$ ), and using an inquiry teaching strategy in teaching (item D2). The areas in which both veteran and nonveteran teachers indicated a preference for on-site training were: conducting a laboratory session (item D3), demonstrating a manipulative skill (item D6), and employing peer tutoring (item D9). Upon comparing the preferences of middle and high school teachers for the type of training, no significant differences were found.

\section{Discussion}

\section{Needs for professional development}

The perceived professional development needs of Korean inservice and preservice teachers with a chemistry background were found to be very strong (Table 3). The strongest need rated by both inservice and preservice teachers was how to motivate students to learn science. The same result was reported from the studies conducted in the US (Baird and Rowsey 1989, Baird et al. 1994). The perception by Korean teachers of their need to increase motivational skills may be explained by the results of recent international comparison studies. The 
Table 5. Comparison of the preferences of veteran and non-veteran teachers for the type of inservice teacher training.

\begin{tabular}{|c|c|c|c|c|c|c|c|}
\hline \multirow[b]{3}{*}{ Item } & \multicolumn{3}{|c|}{ Veteran teachers } & \multicolumn{3}{|c|}{ Non-veteran teachers } & \multirow{3}{*}{$\begin{array}{c}\mathrm{x}^{2} \\
\text { (veteran versus } \\
\text { non-veteran teachers) }\end{array}$} \\
\hline & \multicolumn{2}{|c|}{ Frequency } & \multirow[b]{2}{*}{$x^{2}$} & \multicolumn{2}{|c|}{ Frequency } & \multirow[b]{2}{*}{$X^{2}$} & \\
\hline & On-site & Online & & On-site & Online & & \\
\hline A1 & 59 & 31 & $8.711^{* *}$ & 7 & 12 & 1.316 & $5.415^{*}$ \\
\hline $\mathrm{A} 2$ & 45 & 43 & 0.045 & 7 & 12 & 1.316 & 1.278 \\
\hline B1 & 27 & 60 & $12.517^{* *}$ & 4 & 14 & $5.556^{*}$ & 0.557 \\
\hline B2 & 26 & 62 & $14.727^{* *}$ & 5 & 14 & $4.263^{*}$ & 0.079 \\
\hline B3 & 20 & 69 & $26.978^{* *}$ & 3 & 16 & $8.895^{* *}$ & 0.417 \\
\hline $\mathrm{C} 1$ & 35 & 50 & 2.647 & 2 & 17 & $11.842^{* *}$ & $6.365^{*}$ \\
\hline $\mathrm{C} 2$ & 31 & 58 & $8.191^{* *}$ & 7 & 12 & 1.316 & 0.028 \\
\hline C3 & 42 & 46 & 0.182 & 7 & 12 & 1.316 & 0.746 \\
\hline D1 & 40 & 47 & 0.563 & 5 & 14 & $4.263^{*}$ & 2.468 \\
\hline D2 & 44 & 44 & 0.000 & 4 & 15 & $6.368^{*}$ & $5.294^{*}$ \\
\hline D3 & 54 & 34 & $4.545^{*}$ & 10 & 9 & 0.053 & 0.496 \\
\hline D4 & 42 & 47 & 0.281 & 7 & 12 & 1.316 & 0.677 \\
\hline D5 & 52 & 34 & 3.767 & 9 & 10 & 0.053 & 1.096 \\
\hline D6 & 67 & 20 & $25.391^{* *}$ & 14 & 4 & $5.556^{*}$ & 0.005 \\
\hline D7 & 25 & 63 & $16.409^{* *}$ & 6 & 13 & 2.579 & 0.076 \\
\hline D8 & 35 & 50 & 2.647 & 5 & 14 & $4.263^{*}$ & 1.449 \\
\hline D9 & 45 & 41 & 0.186 & 10 & 9 & 0.053 & 0.001 \\
\hline D10 & 35 & 53 & 3.682 & 9 & 10 & 0.053 & 0.372 \\
\hline D11 & 21 & 66 & $23.276^{* *}$ & 6 & 13 & 2.579 & 0.455 \\
\hline E1 & 41 & 45 & 0.186 & 7 & 12 & 1.316 & 0.736 \\
\hline E2 & 26 & 61 & $14.080^{* *}$ & 3 & 16 & $8.895^{* *}$ & 1.559 \\
\hline F1 & 35 & 52 & 3.322 & 10 & 8 & 0.222 & 1.430 \\
\hline $\mathrm{F} 2$ & 14 & 74 & $40.909^{* *}$ & 0 & 19 & NA & NA \\
\hline F3 & 16 & 72 & $35.636^{* *}$ & 2 & 17 & $11.842^{* *}$ & 0.654 \\
\hline G1 & 19 & 70 & $29.225^{* *}$ & 1 & 18 & $15.211^{* *}$ & 2.685 \\
\hline $\mathrm{G} 2$ & 17 & 71 & $33.136^{* *}$ & 2 & 17 & $11.842^{* *}$ & 0.827 \\
\hline G3 & 19 & 68 & $27.598^{* *}$ & 2 & 17 & $11.842^{* *}$ & 1.256 \\
\hline G4 & 18 & 70 & $30.727^{* *}$ & 0 & 18 & NA & NA \\
\hline G5 & 29 & 58 & $9.667^{* *}$ & 7 & 12 & 1.316 & 0.086 \\
\hline G6 & 20 & 67 & $25.391 * *$ & 5 & 13 & 3.556 & 0.189 \\
\hline
\end{tabular}

${ }^{*} p<0.05,{ }^{* *} p<0.01$ 
Third International Mathematics and Science Study conducted in 1995 and the Third International Mathematics and Science Study-Repeat in 1999 revealed a decreasing tendency of Korean secondary school students to view science and science classes with interest (Korea Institute of Curriculum and Evaluation 2000). Korea was one of the lowest ranked countries among the countries participating in the Third International Mathematics and Science Study and the Third International Mathematics and Science Study- Repeat in the variables associated with students' attitudes toward science, although Korea ranked fairly high in science achievement. It was reported that only $10 \%$ of Korean students had positive attitudes toward science, which is quite low compared with the results of other countries such as Malaysia (72\%), Jordan (59\%), and Singapore (46\%). Therefore, Korean inservice and preservice teachers were more concerned about students' low motivation, and strove to obtain more information about the ways to effectively motivate their students to learn science.

It might be interesting to compare teachers' perceived needs for inservice training across countries. Abu Bakar et al. (1988) reported that there existed similarities in the patterns of science teachers' prominent needs for their professional development across countries including both developing countries such as Jordan and Malaysia and developed countries such as the US. Although they could not derive any explicit conclusion about the reason for these similarities in teachers' needs, they proposed a noteworthy explanation - a strategic influence of science teacher training procedures in the US on developing countries through the importation and adaptation of curricula and the training of teacher educators by the universities and colleges in the US (Abu Bakar et al. 1988). Korea may be also one of the countries whose educational system has been considerably influenced by the US.

In order to compare the results of this study with those of some previous studies, we classified teachers' responses to each of needs assessment items into dichotomous classes - either perceived or not perceived as needs - as Baird and Rowsey (1989) did. That is, the responses of 'Great' and 'Moderate' in the four-point scale were combined into a single class labelled 'Need', while responses of 'Little' and 'Not at all' were combined into a second class labelled 'No need'. Chisquare analyses were then used to examine the distribution of teachers' perceived needs for each item with expected frequencies of 50\% for each of the above two classes. Table 6 presents the percentages of 
Table 6. Comparison of rank-ordered needs in three studies.

\begin{tabular}{|c|c|c|c|c|c|c|}
\hline \multirow[b]{2}{*}{ Item } & \multicolumn{2}{|c|}{ Present study } & \multicolumn{2}{|c|}{ Baird and Rowsey (1989) } & \multicolumn{2}{|c|}{ Baird et al. (1994)a } \\
\hline & Rank & Need (\%) & Rank & Need (\%) & Rank & Need (\%) \\
\hline D1 & 1 & $100.0^{* *}$ & 1 & $80.1^{* *}$ & 1 & 79.1 \\
\hline G1 & 2 & $100.0^{* *}$ & 6 & $66.4^{* *}$ & 8 & 64.3 \\
\hline $\mathrm{C} 2$ & 3 & $99.2^{* *}$ & 13 & $60.0^{*}$ & 15 & 56.8 \\
\hline D3 & 4 & $98.3^{* *}$ & 17 & 58.8 & 18 & 52.3 \\
\hline $\mathrm{G} 2$ & 4 & $98.3^{* *}$ & 8 & $64.1^{* *}$ & 9 & 64.0 \\
\hline $\mathrm{F} 2$ & 6 & $97.5^{* *}$ & 2 & $78.2^{* *}$ & 2 & 76.1 \\
\hline G3 & 7 & $96.6^{* *}$ & 5 & $69.1^{* *}$ & 5 & 68.6 \\
\hline D11 & 8 & $96.6^{* *}$ & 3 & $69.8^{* *}$ & 3 & 75.2 \\
\hline B2 & 9 & $95.8^{* *}$ & 16 & 59.1 & 12 & 58.8 \\
\hline G4 & 10 & $95.8^{* *}$ & 4 & $69.1^{* *}$ & 4 & 68.7 \\
\hline B1 & 11 & $95.7^{* *}$ & 21 & 52.2 & 17 & 53.7 \\
\hline B3 & 12 & $95.0^{* *}$ & 15 & $59.8^{*}$ & 19 & 52.2 \\
\hline C3 & 13 & $95.0^{* *}$ & 19 & 54.7 & $-{ }^{b}$ & $-\mathrm{b}$ \\
\hline D4 & 13 & $95.0^{* *}$ & 23 & 49.8 & 26 & 47.8 \\
\hline D2 & 15 & $94.1^{* *}$ & 11 & $62.3^{*}$ & 7 & 64.7 \\
\hline D5 & 15 & $94.1 * *$ & 22 & 51.0 & 24 & 48.9 \\
\hline $\mathrm{A} 1$ & 17 & $93.3^{* *}$ & 30 & $33.8^{* *}$ & $-^{\mathrm{b}}$ & $-^{\mathrm{b}}$ \\
\hline D6 & 18 & $93.3^{* *}$ & 24 & 49.1 & 22 & 49.2 \\
\hline D8 & 18 & $93.3^{* *}$ & 18 & 56.8 & 14 & 57.5 \\
\hline D10 & 18 & $93.3^{* * *}$ & 26 & 48.1 & 21 & 50.8 \\
\hline E1 & 21 & $93.2^{* *}$ & 7 & $64.5^{* *}$ & 10 & 63.9 \\
\hline F3 & 22 & $92.4^{* *}$ & 12 & $62.1^{*}$ & 11 & 59.7 \\
\hline D7 & 23 & $91.6^{* *}$ & 10 & $62.6^{*}$ & $-\mathrm{b}$ & $-^{\mathrm{b}}$ \\
\hline F1 & 23 & $91.6^{* *}$ & 14 & $59.9^{*}$ & 16 & 55.8 \\
\hline G6 & 25 & $90.7^{* *}$ & 28 & 44.4 & 20 & 52.1 \\
\hline E2 & 26 & $89.9^{* *}$ & 9 & $63.8^{* *}$ & 6 & 64.9 \\
\hline G5 & 26 & $89.9^{* *}$ & 27 & 45.4 & 23 & 49.1 \\
\hline D9 & 28 & $88.2^{* * *}$ & 20 & 52.5 & 13 & 58.0 \\
\hline C1 & 29 & $86.6^{* *}$ & 29 & 40.8 & 27 & 35.3 \\
\hline $\mathrm{A} 2$ & 30 & $85.0^{* *}$ & 25 & 48.6 & 25 & 48.0 \\
\hline
\end{tabular}

a. Data for statistical probabilities were not available.

b. Items that were not surveyed.

${ }^{*} p<0.05,{ }^{* *} p<0.01$.

'Need' for each item in descending order. It also displays the results of the two previous studies with secondary science teachers in the US (Baird and Rowsey 1989, Baird et al. 1994). 
Although there is a gap of five years between the two previous studies, the results show a similar trend in science teachers' perceived needs. The results of this study, however, exhibited a sharp contrast with them. Korean teachers' needs are so strong that the percentages of 'Need' in all 30 items are significantly above expected frequencies at the 0.01 level. These compare interestingly with the results of the other two studies, in which only about one-half of items are rated significantly above expected frequencies. In their studies, teachers' prominent needs also tend to be centered on three categories (delivering instruction, administering instructional facilities and equipment, and improving personal competence as a teacher) out of seven original categories of the STIN. Abu Bakar et al. (1988) also reported that the prominent needs perceived by Jordanian secondary science teachers were mainly from the above three categories plus 'managing instruction', while those by Malaysian teachers from the same four categories plus 'specifying objectives for instruction'. On the other hand, Korean teachers expressed their needs not only in the three shared categories among the teachers from the three respective countries, but also in the other four categories (specifying objectives for instruction, diagnosing and evaluating learners, planning instruction, and managing instruction) that are closely related to preparing/giving instructions and evaluation. These results are consistent with a report that science teachers in Korea tended to be less confident of their preparation for teaching science than those in other countries participating in the Third International Mathematics and Science Study-Repeat (Korea Institute of Curriculum and Evaluation 2000). The findings may imply that there are certain weaknesses in science teacher preparation in Korea, especially in fostering preservice teachers to acquire a range of skills and techniques that are necessary for teaching science and evaluating students. The curricula of the colleges of education in Korea have been frequently criticized with respect to the following: teacher preparation programs are too academic and not directly relevant to teaching practices, and four to six weeks of teaching practice, compared with a half-year or a full year of student teaching or internship in many countries, is neither sufficiently intense nor integrated with the content taught in the colleges (Noh and Jeong 2002).

Means of preservice teachers' needs were found to be higher than those of inservice teachers' needs in 24 items (Table 3), of which six (items A2, D11, E1, E2, G4, and G5) were statistically significant. The 
only area that inservice teachers needed significantly more help than preservice teachers was in identifying sources of free instructional materials (item F2), which is a practical aspect in preparing for teaching their own science classes. These results were expected given the fact that preservice teachers with little or no teaching experience undoubtedly need greater help in many aspects of preparing for what they are expected to perform as science teachers. It is also interesting to note that among the six items in which preservice teachers perceived a significant need for more help than inservice teachers, two (items D11 and E2) are related to using computers. It may be widely accepted that older teachers are usually more anxious about using computers because they were not raised in the computer age (Okinaka 1992). However, preservice teachers who are expected to be generally more familiar with and skillful at using computers were found to ask for more help in using computers for teaching and managing instruction than their inservice counterparts. This tendency may reflect the increasing importance of technology in science teaching and preservice teachers' interest in teaching science with technology.

Unlike the results of Germann and Barrow (1995), in which nonveteran teachers exhibited greater interests in science content and teaching methods, no significant differences between veteran and nonveteran teachers were found in this study. This may be partly due to a ceiling effect, because item means ranging from 3.21 to 3.75 on a four-point Likert scale may be too high to effectively compare. When the needs of middle school and high school teachers were compared, middle school teachers were found to have stronger needs for using test items to diagnose learning difficulties (item B2), using an inquiry teaching strategy in teaching (item D2), demonstrating a science process skill (item D5), and employing individualized instruction (item D8). These results may be related to the very competitive environment in Korea for high school graduates to enter prestigious universities and colleges (Noh et al. 1997). Many Korean high school graduates spend one year or two years to prepare for entrance examinations in private informal schools as a supplement to regular formal schooling. Many students also take lessons in academic subjects important in the entrance examinations after school, which has been a social problem. Under these conditions, high school teachers are less likely to pay attention to inquiry teaching methods and individual learning differences. 


\section{Preferences for on-site and online training}

Korean teachers possessing a chemistry background generally tended to prefer online inservice teacher training to traditional onsite programs (Table 4 ). This result appears to be consistent with the assertions suggested by many researchers who emphasized the possibility of online teacher training as an alternative to a traditional on-site program, which possesses practical obstacles of being present at a training site at a designated time (Baek and Westrom 2001, Barkley 2001, Jung 2001). That is, teachers seemed to prefer online inservice training because it enables them to overcome the problem of time and space when they want the opportunities for professional development. Korean teachers' preference for online training, however, might be also related to their readiness in using computers. According to the teachers' responses to the questions concerning access to and use of the Internet, well-equipped network connections were available to most Korean teachers in their school and/or at home. This situation may lead them to possess considerable amount of experience in using the Internet. Indeed, many teachers frequently used the Internet in searching for instructional resources, and were satisfied with the results of their search using the Internet (Table 2). Compared with teachers in other countries, Korean teachers seem to be technically well prepared, and therefore there may be less reluctant to accept online training.

However, it is unreasonable and even impossible to substitute all traditional onsite inservice teacher training programs for online training programs. In five areas, more teachers preferred on-site to online training. There were also many teachers (13-48\%) who still preferred on-site training in the remaining areas, because they may need direct experience and/or interaction in learning some areas, as their students need direct experience in the laboratory of science courses. Teachers who responded to this questionnaire also seemed to designate this point. They exhibited statistically significant preferences for traditional on-site training in the items regarding conducting laboratory sessions (item D3) and demonstrating manipulative skills (item D6). Questions can be raised as to the reasons for teachers' preference for the traditional on-site training in defending the reasons for teaching science (item A1). This result might reflect Korean teachers' lack of confidence in justifying the necessity of school science, although 
they had acquired a lot of information from textbooks and science education courses in colleges of education. They appeared to need more plausible reasons for teaching science through a face-to-face discussion with experts on education.

Although preservice teachers favored online training in 18 items, their preferences for traditional on-site training tended to be stronger than those of inservice teachers. The items in which preservice teachers exhibited statistically significant preferences for on-site rather than online training were: writing objectives (item A2), designing measurement items (item B1), demonstrating concepts (item D4), demonstrating process skills (item D5), knowledge about cognitive learning theories (item G5) and knowledge about history and philosophy of science (item G6), as well as the three items (A1, D3, and D6) designated by inservice teachers. It seems that these stronger preferences by preservice teachers for traditional on-site training may be due to their amount of teaching experience. That is, without a doubt, preservice teachers do not possess enough experience with actual teaching, and this might lead them to be less confident of, or sometimes to be anxious about, their capability as science teachers. Traditional on-site instructional programs, unlike online ones, could provide preservice teachers with more direct and practical experience to overcome their anxiety. As a result, preservice teachers still want to have on-site instruction through face-to-face interaction rather than on-line instruction in learning key elements, although they are more accustomed to and more skillful in using computers and the Internet than inservice teachers. The finding that the aforementioned nine areas are from four of seven categories suggests that an online program on chemical education can be used not as a substitute for a traditional on-site course, but as supplementary information.

Although no significant differences were found in the comparisons of teachers' preferred types of inservice training by their school level, some differences were found by their teaching experience. Non-veteran teachers tended to prefer online training in 26 items (Table 5). The percentage of non-veteran teachers who preferred online training programs to on-site ones were higher than those of veteran teachers in 21 items, and the differences were statistically significant in three items (A1, C1, and D2). Among the three items (A1, D3, and D6) in which inservice teachers exhibited stronger preferences for traditional on-site training, only a significant difference was found in 
demonstrating manipulative skills for non-veteran teachers, while the same three differences were found for veteran teachers. The difference between veteran and non-veteran teachers in their preferences for the type of training, however, was not so remarkable, compared with the differences between inservice and preservice teachers. Although many Korean teachers did use technology frequently and no remarkable differences between veteran and non-veteran teachers in the responses to the use of the Internet were noticed, some veteran teachers still seemed to be less comfortable with technology as expected (Okinaka 1992). Therefore, more content on using technology and its integrated materials are needed, especially for some veteran teachers who do not feel comfortable with technology.

\section{Implications}

Teachers who possess a strong teaching background, and who are well equipped with a wide repertoire of instructional strategies to use, could teach their students more effectively. This study indicated prominent areas, designated by Korean inservice and preservice teachers majoring in chemical education, as necessary to enhance their professional development. If we expect teachers to do a better job and to improve education, the needs perceived by inservice and preservice teachers for their professional development should be accounted for when planning future teacher training and preparation programs. Especially in Korea, closer attention should be paid to the curriculum of preservice teachers' programs in order to improve their ability and confidence in teaching science, because even inservice teachers were found to be less confident in their readiness in teaching science than we expected.

Korean teachers with a chemistry background generally possessed favorable impressions toward using the Internet and generally preferred online inservice teacher training to traditional on-site programs. Introducing an online inservice teacher training system has many advantages over an on-site one, which includes less restriction in time and space, and more latitude for teachers to choose their own inservice training programs (Baek and Westrom 2001, Barkley 2001, Jung 2001, Levins et al. 1994). Another advantage of an online training system is from the viewpoint of using information technology in 
education. The positive impacts of using the Internet are largely accepted and the continued growth of the Internet is unquestionable (Gray 1996). Undoubtedly, teachers themselves should also be prepared and supported to effectively teach their students concerning the use of technical resources, as is the case with any innovation. However, teachers should be motivated first. One way to do this is by letting them experience the benefits of innovation in their own learning (Vázquez-Abad 1999). Introduction of on-line training systems may be one such effective way for teachers to experience new technology. This suggestion is also in harmony with the recommendation of integrating computer competencies into appropriate areas of the curriculum as a way of follow-up support for strengthening technology staff development (Bradshaw 2002).

On planning inservice teacher training and teacher preparation programs, however, it is desirable that an online training system be supplemented with an onsite one, because the online system could never be the only solution in presenting all content and activities effectively. Some potential users, especially preservice teachers and veteran teachers in this study, also related a preference for on-site instruction. For preservice teachers with little or no teaching experience, direct interaction seems to be a better way to study some key elements of learning and instruction, assessment, and the nature of science. If an online program is implemented for preservice teachers, practical examples of the implementation of educational theories and teaching strategies of using synchronous and/or asynchronous communication tools for web-based instructions should be well prepared. For the users, especially some veteran teachers, who do not feel comfortable with technology, activities to improve teachers' computer literacy should continuously be assembled (Littlejohn 2002). Networking teachers via the Internet, which makes a connection between veteran teachers of strong knowledge in instruction and nonveteran teachers of computer competence, might be another effective way to increase teachers' self-efficacy toward science teaching with/without technology (Mathew et al. 1998).

Acknowledgements - This work was financially supported by a grant (2000-250100-001-3) from the Korea Science and Engineering Foundation. 


\section{References}

Abu Bakar, K. and Tarmizi, R.A. (1995). Teacher preparation concerns: professional needs of Malaysian secondary school science teachers. Paper presented at the Annual Meeting of the Association for the Education of Teachers in Science, Charleston, VA, 5-8 January.

Abu Bakar, K.H., Rubba, P.A., Tomera, A.N. and Zurub, A.R. (1988). Jordanian and Malaysian science teachers' prominent perceived professional needs: a comparison. Journal of Research in Science Teaching, 25(7), 573-587.

Baek, Y.-K. and Westrom, M. (2001). Building a cyber training center for teachers in Korea. Journal of Technology and Teacher Education, 9(2), 171-179.

Baird, W.E. and Rowsey, R.E. (1989). A survey of secondary science teachers' needs. School Science and Mathematics, 89(4), 272-284.

Baird, W.E., Easterday, K., Rowsey, R.E. and Smith, T. (1993). A comparison of Alabama secondary science and mathematics teachers: demographics and perceived needs. School Science and Mathematics, 93(4), 175-182.

Baird, W.E., Prather, J.P., Finson, K.D. and Oliver, J.S. (1994). Comparison of perceptions among rural versus nonrural secondary science teachers: a multistate survey. Science Education, 78(6), 555-576.

Barkley, S.G. (2001). Online learning for teachers. Streamlined Seminar, 20(1), 1-2.

Barkley, S. and Bianco, T. (2001). Online and onsite training: when to mix, when to match. Educational Technology, 41(4), 60-62.

Bell, B. (1998). Teacher development in science education. In B.J. Fraser and K.G. Tobin (eds.) International Handbook of Science Education (Dordrecht: Kluwer Academic Publishers), 681-693.

Boone, W.J. and Andersen, H.O. (1995). Training science teachers with fullyinteractive, distance education technology. Journal of Science Teacher Education, 6(3), 146-152.

Borg, W.R. and Gall, M.D. (1989). Educational Research: an Introduction (New York: Longman).

Bradshaw, L.K. (2002). Technology for teaching and learning: strategies for staff development and follow-up support. Journal of Technology and Teacher Education, 10(1), 131-150.

Buchanan, M. (1995). Can the Internet be used with K-5 students? the answer is elementary! Technology Connection, 2(4), 20-22.

Burden, P.R. (1979). Teachers' perceptions of the characteristics and influences on their personal and professional development. Unpublished doctoral dissertation, The Ohio State University.

Eraut, M. (1995). Inservice teacher education. In L.W. Anderson (ed.) International Encyclopedia of Teaching and Teacher Education, 2nd edn. (Cambridge: Pergamon Press), 620-628.

Fullan, M.G. and Miles, M.B. (1992). Getting reform right: what works and what doesn't. Phi Delta Kappan, 73(10), 744-752. 
Germann, P.J. and Barrow, L.H. (1995). Inservice needs of teachers of biology: a comparison between veteran and nonveteran teachers. American Biology Teacher, 57(5), 272-277.

Gray, M. (1996). Internet statistics: growth and usage of the Web and the Internet. Available online from: http://www.mit.edu/people/mkgray/net/ index.html (accessed 19 May 2003).

Halla, M. and Lehman, C.B. (1992). Doing science in the electronic school district. Journal of Computers in Mathematics and Science Teaching, 11(2), 193-198.

Howe, A.C. and Stubbs, H.S. (1997). Empowering science teachers: a model for professional development. Journal of Science Teacher Education, 8(3), 167-182.

Jung, I. (2001). Issues and challenges of providing online inservice teacher training: Korea's experience. International Review of Research in Open and Distance Learning, 2(1), 1-18.

Kim, J.-K., Kim, I.-H., Jeong, G.-J., Kim, B.-G. and Koo, I.S. (1991). Improvement ways for inservice training of science teachers. Journal of Korean Association for Research in Science Education, 11(1), 97-115 (in Korean).

Knapczyk, D., Chapman, C., Rodes, P. and Chung, H. (2001). Teacher preparation in rural communities through distance education. Teacher Education and Special Education, 24(4), 402-407.

Korea Institute of Curriculum and Evaluation (2000). Reports on the Third International Mathematics and Science Study-Repeat (TIMSS-R). ORM 200016 , Seoul.

Korea Multimedia Education Center (1998). Educational informatization evaluation report: Inservice teacher training evaluation. Internal report, Seoul.

Korean Federation Of Teachers' Associations (1999). The Korean Directory of Education (Seoul: Korean Federation of Teachers' Associations).

Levins, L., Pegg, J. and Creedy, L. (1994). A program for professional development of secondary science teachers. Australian Science Teachers Journal, 40(1), 37-41.

Little, R.J.A. and Rubin, D.B. (1987). Statistical Analysis with Missing Data (New York: John Wiley \& Sons).

Littlejohn, A.H. (2002). Improving continuing professional development in the use of ICT. Journal of Computer Assisted Learning, 18(2), 166-174.

Loughran, J. and Gunstone, R. (1997). Professional development in residence: developing reflection on science teaching and learning. Journal of Education for Teaching, 23(2), 159-178.

Mathew, N.M., Barufaldi, J.P. and Bethel, L.J. (1998). The effect of electronic networking on preservice elementary teachers' science teaching self-efficacy. Paper presented at the Annual Meeting of the National Association for Research in Science Teaching, San Diego, CA, 19-22 April.

McGinnis, J.R., Simmons, P., Atwater, M.M., Hatfield, L., Olive, J. and Hunt, A. (1996). Beliefs and perceived needs of rural K-12 teachers of science toward the uses of computing technologies. Journal of Science Education and Technology, $5(2), 111-120$. 
Mecca, P.M. and Klindienst, D.B. (1987). Science Needs Assessment Project: a look at science education in Pennsylvania. Paper presented at the Annual Meeting of the National Association for Research in Science Teaching, Washington, DC, 2325 April.

Noh, T. and Jeong, Y. (2002). Teaching practice programs. Journal of Research in Subject Matter Education, 6(1), 407-424 (in Korean).

Noh, T., Han, I., Woo, K. and Kang, S. (1997). Chemical education in Korea. In Y. Takeuchi and M.M. Ito (eds.) Chemical Education in Asia-Pacific (Tokyo: The Federation of Asian Chemical Society), 58-74. Available online from: http:// www.t.soka.ac.jp/chem/CEAP/Korea13.html (accessed 19 May 2003).

Okinaka, R. (1992). The factors that affect teacher attitude towards computer use. ERIC Document Reproduction Service Number ED 346039.

Organization For Economic Co-operation And Development (2001). OECD Communications Outlook 2001 (Paris: OECD Publications Service).

O'Sullivan, M.C. (2000). Needs assessment for INSET for unqualified primary teachers in Namibia: an effective model. Compare, 30(2), 211-234.

Packwood, T. and Whitaker, T. (1988). Needs Assessment in Post-16 Education (Lewes: Falmer Press).

Ramsey, J. (1993). A survey of the perceived needs of Houston-area middle school science teachers concerning STS goals, curricula, inservice, and related content. School Science and Mathematics, 93(2), 86-91.

Robinson, B. (1991). Distance education for inservice teacher education in the United Kingdom. Action in Teacher Education, 13(3), 60-63.

Robinson, M. (1994). Using email and the Internet in science teaching. Journal of Information Technology for Teacher Education, 3(2), 229-238.

Seferoglu, S.S. (1996). Exploring elementary school teachers' perceptions of professional development: The Turkish case. Paper presented at the Annual Meeting of the American Educational Research Association, New York, 8-12 April.

Sherry, L. and Morse, R. (1995). An assessment of training needs in the use of distance education for instruction. International Journal of Educational Telecommunications, 1(1), 5-22.

Sumrall, W.J. and Sumrall, C.M. (1995). Introducing electronic mail applications within preservice elementary science methods courses. Journal of Computing in Teacher Education, 11(4), 23-30.

Vázquez-Abad, J. (1999). 'Hebdo-Chim', a Web application to support learning in a chemistry methods pre-service course. Journal of Science Education and Technology, 8(4), 283-290.

Walker, A. and Cheong, C.Y. (1996). Professional development in Hong Kong primary schools: beliefs, practices, and change. Journal of Education for Teaching, 22(2), 197-212.

Wiesenmayer, R.L. and Koul, R. (1998). Integrating Internet resources into the science classroom: teachers' perspectives. Journal of Science Education and Technology, 7(3), 271-277. 
Witkin, B.R. (1984). Assessing Needs in Educational and Social Programs: using Information to Make Decisions, Set Priorities, and Allocate Resources (San Francisco, CA: Jossey-Bass Publishers).

Wood, M.G. (1992). LabNet: toward a community of practice. Hands On, 15(2), 9-11.

Zint, M. and Peyton, R.B. (2001). Improving risk education in grades 6-12: a needs assessment of Michigan, Ohio, and Wisconsin science teachers. Journal of Environmental Education, 32(2), 46-54.

Zurub, A.R.A. (1982). An assessment of need among secondary level Jordanian science teachers. Unpublished doctoral dissertation, Southern Illinois University at Carbondale.

Zurub, A.R. and Rubba, P.A. (1983). Development and validation of an inventory to assess science teacher needs in developing countries. Journal of Research in Science Teaching, 20(9), 867-873. 